\title{
El adulterio y la violencia femenina en algunos pliegos sueltos poéticos del siglo XVI
}

\author{
Adultery and Female Violence \\ in some Poetic Spanish Chapbooks of the $16^{\text {th }}$ Century
}

\author{
María Sánchez-Pérez \\ Universidad de Salamanca
}

\section{RESUMEN}

El objetivo de este trabajo es estudiar el tratamiento del adulterio y la violencia femenina en pliegos sueltos poéticos del siglo XVI. Mediante un recorrido por varios casos veremos cómo la mujer adúltera comete todo tipo de atrocidades y asesinatos para gozar libremente de su amante. En ocasiones asesinará al marido, pero también a todos aquellos que se interpongan en su relación. Se nos presenta así la imagen de una mujer libidinosa, cruel y peligrosa, de acuerdo con la concepción y la mentalidad de la época.

Palabras clave: Adulterio, Violencia, Pliegos sueltos poéticos, Literatura popular, España.

\section{SUMMARY}

The aim of this article is to study the depiction of adultery and female violence in poetic chapbooks of the $16^{\text {th }}$ century. By going over several cases we will show that adulterous women perform all kinds of atrocities and killings to enjoy her lover freely. Occasionally she will murder her husband, but also anyone who comes between their relationship. The image we get, then, is that of a lustful, cruel and dangerous woman, according to the mentality of the time.

Key words: Adultery, Violence, Poetic Spanish Chapbooks, Popular Literature, Spain.

Las relaciones de sucesos en pliegos sueltos poéticos es un género que comenzó su andadura a finales del siglo XV, pero cuyo desarrollo y éxito masivo se fraguó a partir de la segunda mitad del siglo XVI. Son varias las líneas temáticas que cabe englobar dentro de estas relaciones de sucesos, ya que se han conservado narraciones de carácter histórico-político -batallas, paces, pero también bodas y exequias, por ejemplo-, historias de cautivos y renegados, composiciones que tratan de desastres naturales -incendios, terremotos, etc.-, descripciones de martirios, etc. ${ }^{1}$. Sin embargo, uno de los subgéneros que más éxito alcanzó a lo largo de la historia de los pliegos

\footnotetext{
${ }^{1}$ Como estudios de conjunto dedicados íntegramente a las relaciones de sucesos pueden verse, García de Enterría (1996), López Poza y Pena Sueiro (1999), Paba (2003), López Poza (2006), Bégrand (2006 y 2009), Espejo Cala (2008), Civil, Crémoux y Sanz (2008).
} 
de cordel fueron los llamados casos horribles y espantosos ${ }^{2}$. En ellos se refieren todo tipo de conductas amorales, homicidios, venganzas, torturas, etc. El tremendismo y el aspecto sensacionalista que destilan todas estas composiciones contribuyeron a propiciar su difusión masiva. Dentro de este subgénero de los casos horribles y espantosos queremos fijar nuestra atención ahora en aquellos que tratan del adulterio y, como de éste, en más de una ocasión, llegamos a encontrar a la mujer ejerciendo distintos tipos de violencia sobre quienes se interponen en esa relación adúltera.

Las narraciones de infidelidades conyugales se encuadran dentro de estas composiciones tremendistas, ya que en todos los casos conservados esa infidelidad conlleva el asesinato de una o varias personas y el posterior castigo, tortura y muerte de los culpables. Como hemos señalado, estos casos horribles y espantosos de adulterio y violencia femenina comienzan a proliferar a mediados del Quinientos. Caro Baroja, refiriéndose a la venta masiva de este tipo de obras, afirmaba: "la pasión es un tema de reflexión moral y filosófica ya en los grandes trágicos. Para el pueblo español es un tema religioso por un lado; un tema con una fuerza vital irresistible por otro" (Caro Baroja 1990: 526). Estas piezas gustan, en efecto, por ser historias donde se dan cita el amor, la violencia y los crímenes; de ahí que existiera un gran público consumidor de ellas.

El principal objetivo de las relaciones de sucesos era informar, dar noticia al público de determinados hechos. No podemos soslayar el hecho de que estas obras supusieron los inicios de nuestro periodismo, son los primeros pasos de este fenómeno, de ahí que nos encontremos ante auténticos especímenes protoperiodísticos (ver, entre otros, los trabajos de Redondo 1995a, 1995b; y Etttinghausen 1995). Sin embargo, junto a la finalidad informativa, al tratarse de obras literarias -de mayor o menor calidad-, se conjugan también otros fines, como son entretener, persuadir o mover los afectos. Además, algunos de estos casos horribles y espantosos tenían un claro fin moralizante y ejemplificador.

Las noticias que transmiten a lo largo de la historia las relaciones de sucesos impresas en pliegos sueltos -especialmente las que se encuentran en verso- serán informaciones verdaderas o ficticias, pero siempre verosímiles. En ocasiones, importaba más la moralización o el didactismo que la veracidad de los hechos. Es cierto que en las narraciones de carácter histórico-político el punto de partida es casi siempre un hecho real incuestionable -batalla de Lepanto, muerte de Isabel de Valois, por poner solo un par de ejemplos-, pero en las historias de cautivos y renegados o incluso en las relaciones sobre desastres naturales -especialmente los que se sitúan fuera de nuestras fronteras- es muy difícil desentrañar el grado de fiabilidad de los sucesos que ahí aparecen. Lo mismo ocurre con los casos horribles y espantosos, pero el nivel de verosimilitud con el que están construidas estas historias hace que para los oyentes y lectores del Siglo de Oro -y, probablemente, aun después- pudieran ser aceptadas como auténticas y verdaderas. La mentalidad y el ideario colectivo de aquella época -de imperativo masculino, fundamentalmente- sustentan y vertebran todas estas obras, como veremos a continuación.

Todos los casos horribles y espantosos conservados, o bien son anónimos, o bien

${ }^{2}$ Estudiamos en otro lugar la trayectoria que han seguido estos casos horribles y espantosos desde sus orígenes hasta el siglo Xxi, ver Sánchez Pérez (2011b). 
han sido compuestos por copleros populares ${ }^{3}$, varones obviamente -del mismo modo que sucede con el resto de relaciones de sucesos-. La voz femenina queda, por lo tanto, silenciada y serán estos autores quienes reflejen su visión de la mujer que, no lo olvidemos, vendría a coincidir, en la mayor parte de las ocasiones, con la mentalidad popular de la época.

En todos los casos horribles y espantosos del siglo XVI que hemos conservado en pliegos sueltos poéticos, el adulterio siempre será cometido por mujeres. Desde siempre, el adulterio masculino -aunque criticado por los teólogos- era tolerado y solo vagamente censurado, mientras que la infidelidad femenina era reprobada y denostada duramente. Ya en la Biblia se estipulaba claramente qué se entendía por adulterio: mientras que la mujer era siempre adúltera, el hombre solo lo era cuando lo cometía con una mujer casada. Es decir, era el estado civil de la mujer lo que definía el adulterio (Deuteronomio 22: 22). Ahora bien, mientras que la Iglesia consideraba el adulterio -masculino y femenino- como un pecado y, por tanto, como un delito, la justicia civil únicamente lo consideraba así cuando lo cometía la mujer ${ }^{4}$. Lo más frecuente además, en la época que nos ocupa y ya desde la Edad Media, es que si una mujer era descubierta manteniendo relaciones extraconyugales la justicia entregara a los adúlteros -junto con los bienes de la esposa- al marido para que él hiciese con ellos lo que desease, sin excluir que pudiese matarlos 5 . Sin embargo, en los casos que veremos a continuación, la mayor parte de las veces el marido no puede defender su honor porque es asesinado por la esposa infiel para poder gozar libremente de "su amigo". Será entonces la justicia civil quien imponga la pena a los culpables.

Teniendo en cuenta, por tanto, que siempre encontraremos adulterio femenino, en estas relaciones de sucesos tremendistas las mujeres representadas terminan cometiendo una serie de crímenes y asesinatos, movidas por los impulsos del amor. Habrá casos en los que se encuentran enamoradas de algún joven diferente al que su padre les ofrece por esposo -mediante un matrimonio previamente concertado-, en otras ocasiones, está casada y mantiene tratos carnales con un hombre distinto de su esposo, por lo que no duda en asesinar al marido para gozar libremente del amante. Como no podía ser de otro modo, la mujer y sus cómplices serán castigados y ajusticiados,

\footnotetext{
${ }^{3}$ Para quienes estén interesados en conocer mejor el mundo que rodea a estos copleros o "ruiseñores" populares - muchas veces identificados con los ciegos-, así como la invención, venta y difusión de estas obras resulta imprescindible el estudio de Cátedra (2002).

${ }^{4} \mathrm{La}$ consideración de que solamente la mujer delinque cuando comete adulterio "se mantuvo a lo largo de toda la Edad Moderna, sobrevivió a la implantación del estado liberal y [...] penetró holgadamente en el siglo XX" (Mendoza Garrido 2008: 175).

5 "A partir del reinado de los Reyes Católicos se trató de someter a control este uxoricidio legalmente establecido en el marco de un adulterio y superar la resolución exclusivamente privada de este asunto. Los monarcas no derogaron las leyes que les otorgaban a los maridos y familiares ultrajados el derecho a vengarse de los adúlteros, pero sí limitaron su acceso a través del filtro de los tribunales de justicia. Nadie podría tomarse la justicia por su mano sin que antes hubiera pasado por los tribunales para demostrar la infidelidad cometida y tras hacerlo, entonces sí, el marido era facultado por el juez para realizar con su esposa infiel y su amante lo que considerara oportuno, desde darles muerte hasta perdonarles la vida. De este modo el marido se convertía en verdugo legalmente investido que ejecutaba públicamente, y no en privado, su venganza en el patíbulo de la localidad y ante toda la comunidad vecinal, recuperando de este modo su honor mancillado" (Bazán 2007: 313; ver también Bazán 2006).
} 
no solamente por el adulterio en sí, sino por los crímenes cometidos para poder llevarlo a cabo. Obviamente el origen de todos los vicios y males ha sido esa infidelidad femenina que, como veremos, se produce por distintos motivos.

Un caso bastante singular es la denuncia que realiza uno de estos copleros populares de la ociosidad como desencadenante del adulterio. La composición lleva por título: Obra nueva y muy verdadera donde se trata el doloroso successo que succedió en la villa de Sant Clemente, en el mes de henero del año 1586, de la dolorosa muerte que dio una muger a su marido, por casarse con su amigo, y fue en su ayuda una tía suya y su amigo, y de la justicia que dellos se bizo. Compuesta por Francisco Gonçales de Figueroa, privado del sentido visivo. Con dos villancicos al cabo ${ }^{6}$.

Pocos datos conocemos acerca de este autor -como suele ser habitual en esta literatura de cordel-, aunque se han conservado varios pliegos más atribuidos a él y sabemos que era oriundo de Murcia y ciego, tal y como se indica eufemísticamente mediante la expresión "privado del sentido visivo" (Askins 1981: 18-19). Este avezado ciego coplero produjo obras de signo muy distinto, aunque siguiendo los dictados y modas de su época ${ }^{7}$, de ahí que compusiera obras de temática religiosa, relaciones de sucesos relativas a martirios, casos horribles y espantosos, etc. ${ }^{8}$. Los hechos se sitúan en 1586, en un municipio de la actual provincia de Cuenca, San Clemente, y las dos ediciones conservadas del pliego salieron de unas prensas valencianas con una diferencia de un año. De esta imprenta solamente se señala que estaba «junto al Molino de la Rovella", y por la fecha en las que fueron impresos cabe deducir que pudieron ser los herederos de Juan Navarro o Vicente de Miravet (Delgado Casado 1996). Respecto a los grabados xilográficos que encabezan ambas obras destaca que en cada edición se haya elegido uno distinto. En uno de ellos (RM 230), en la estampa encontramos a un rey sedente, junto con dos personajes en pie, mientras que en el otro (RM 231) sobresale un grabado de gran tamaño ilustrando un cadalso con la horca, dos reos ya colgados y un verdugo subiendo a un tercero al patíbulo. Ya se ha señalado que, en un producto tan barato como el de los pliegos sueltos, la utilización de grabados fue casi obligada, en parte debido a la tradición de leer con los ojos, de la lectura para analfabetos, que dio lugar a toda una iconografía popular (Portús 2000). La elección del grabado con la figura del rey parece indicar la importancia de la aplicación de la justicia, pues recordemos que en todos los casos horribles y espantosos que hemos conservado -independientemente de la temática concreta- ésta siempre termina imponiéndose, ya sea mediante el poder civil o a través de la intervención divina. Por otra parte, el grabado con la estampa de la horca resulta bastante más

\footnotetext{
${ }^{6}$ Se trata de la entrada 231 de la obra de Rodríguez Moñino 1997 (en adelante RM y número de entrada). Se conserva otra edición de la misma obra: RM 230. Para la transcripción y edición de los textos hemos seguido las normas recogidas en el Proyecto de investigación "Cultura popular y cultura impresa", pp. 8-9. Para un acercamiento más detallado de esta obra concreta ver Sánchez Pérez (2005).

${ }^{7}$ Para conocer el cambio de rumbo y de gustos que se observa en las obras que se imprimeron en pliegos sueltos poéticos y que afecta al siglo XVI, consúltese García de Enterría (1983: 32-37).

${ }^{8}$ Además de la obra que antes hemos señalado, véanse, por ejemplo, RM 194, 229, 232. M. a Cruz García de Enterría no duda en asimilar la obra de los copleros Francisco de Figueroa y Francisco González de Figueroa, ya que con toda probabilidad se trata del mismo autor (García de Enterría 1982: 27).
} 
expresivo y posee un carácter disuasorio, ya que uno de los fines que se perseguían a través de la difusión de estas conductas amorales era intentar mantener el orden establecido, según los imperativos de las jerarquías civil y eclesiástica, a través de la provocación del miedo.

En la obra que ahora nos ocupa Francisco González de Figueroa denuncia claramente que el hecho de que la mujer esté ociosa la arrastra a cometer adulterio:

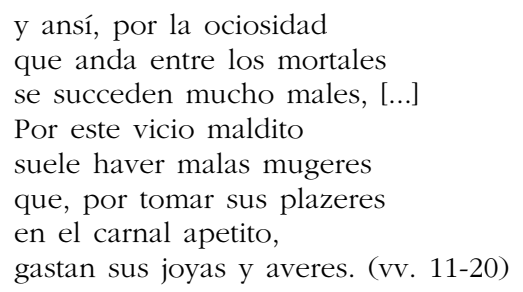

La ociosidad era considerada un grave pecado y solía asociarse a la imagen femenina. Mujeres poco virtuosas que, al permanecer ociosas, se veían abocadas a la infidelidad conyugal. Ya en la Biblia encontramos referencias al hecho de que permanecer ocioso constituía uno de los peores pecados, ya que incitaba a cometer otros, y así podemos leerlo en Tobías 4:13: "la ociosidad lleva a la decadencia y a la miseria; ella es, en efecto, madre de la penuria". Pero, sin duda, los sermones de la época debían recalcar esta idea una y otra vez, de ahí por ejemplo que el franciscano Diego de Estella (1524-1578) dedicara íntegramente un capítulo a la ociosidad en su Tratado de la vanidad del mundo dividido en tres libros, donde afirma: "Sobre todas las cosas huye de la ociosidad, como verdadera madre de vicios y madrastra de virtudes [...]. La ociosidad es hiesca de los pecados sensuales" (Estella 1787: 395-396). Eran de sobra difundidas ideas como estas y, sin duda, los oyentes y lectores del momento las conocerían, entre otras vías, gracias a los sermones de los predicadores ${ }^{9}$, sin olvidar los libros de espiritualidad o las instrucciones de los confesores y moralistas. Por poner solamente un par de ejemplos, dos obras clave del Renacimiento español, De institutione feminae christianae (1523) de Juan Luis Vives -traducida al español en 1528: Instrucción de la mujer cristiana- y La perfecta casada de fray Luis de León (1583) articulaban "una visión apologética de la vida marital" y prescribían "las obligaciones correspondientes a la esposa" (Rivera 2006: 11-12). Según Vives "las mujeres que no saben guardar su castidad merescen tanto mal que no basta la vida para pagallo" (1935: 41) y, en la obra de fray Luis, la perfecta casada es aquella que queda recluida en el ámbito doméstico, que atiende celosamente al marido, que aporta su sexualidad para procrear hijos legítimos, que educa a su progenie obedeciendo los dictados de la moral cristiana y que, de este modo, en definitiva, ayuda a preservar los valores establecidos por las jerarquías civiles y religiosas del momento. En palabras del agustino: "porque, como la mujer sea de su natural flaca y deleznable más que ningún otro animal, y de costumbre e ingenio una cosa quebradiza y melindrosa" (León 1968: 26) no le quedaba más remedio que convertirse en un dechado de virtudes si quería llegar a ser una buena esposa. González de Figueroa, basándo-

\footnotetext{
${ }^{9}$ Para la relación entre copleros y predicadores ver, entre otros, García de Enterría (1990) y Cátedra (2002).
} 
se en los arquetipos negativos sobre las mujeres, alude también a la lujuria como causa de estas infidelidades:

\author{
y la mujer desleal \\ traía al moço turbado \\ en este vicio carnal. (vv. 43-45)
}

La lujuria y el poder seductor de la mujer aparecen también en otros casos horribles y espantosos y a través de ellos se incita a los hombres a cometer adulterio con ellas:

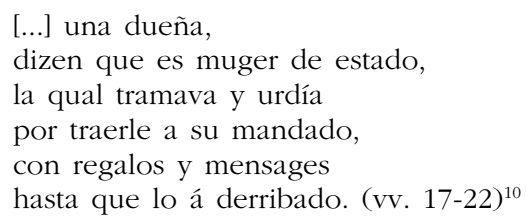

Pero volviendo a la obra de Francisco González de Figueroa ya hemos visto cómo nos presenta a la protagonista o actante de esta composición sobre adulterio femenino y violencia femenina. De ella no se dirá nunca el nombre, pero sí que estaba desposada con un mercader: Gonzalo Díaz. El marido, debido a su profesión, debe ausentarse en demasiadas ocasiones del domicilio conyugal ${ }^{11}$, por lo que su mujer -ociosa y entregada a la lujuria- comienza a mantener relaciones sexuales con un vecino de la villa, llamado Pedro Carrasco. Pasado un tiempo ella pensó "una maldad I que fue caso endemoniado", decidiendo asesinar al marido para gozar libremente del amante. El ciego coplero presenta así la escena:

$$
\begin{aligned}
& \text { Y estando sola a plazer } \\
& \text { con Pedro Carrasco un día, } \\
& \text { dixo: "Mi bien y alegría } \\
& \text { quiero daros a entender } \\
& \text { lo que aflige el alma mía. } \\
& \text { Y es que bivo descontenta } \\
& \text { con aqueste mi marido } \\
& \text { y si Dios fuesse servido } \\
& \text { verme dél libre y essenta } \\
& \text { ternía gozo cumplido. } \\
& \text { "Y estaríamos yo y vos } \\
& \text { juntos a nuestro plazer }
\end{aligned}
$$

\footnotetext{
${ }^{10}$ Se trata de RM 516. La obra lleva por título: Aqui se contiene un doloroso y desastrado caso acontecido a un cavallero y a su muger, que ambos fueron sentenciados a muerte; es caso que se puede tomar exemplo. Iuntamente con éste, otros romances nuevos y muy curiosos y villancicos para reír y passar tiempo. Todo compuesto por Ginés Sánchez de la Cruz, vezino de Valencia. Impressas con licencia. Año de 1596.

${ }^{11}$ Como es evidente, se trata de un artificio más de los que se vale el ciego coplero para construir su historia y que esta resulte verosímil. Por recordar solamente un conocido ejemplo de nuestra literatura mencionaré la fábula del pintor Pitas Payas en el Libro de Buen Amor de Juan Ruiz, donde el marido también debe ausentarse de la casa durante largo tiempo con las consecuencias que eso conlleva.
} 
y augmentarse hía el querer que está puesto entre los dos, que mayor no podía ser.

Vós, lo podéis remediar, Carrasco, amigo y hermano, que todo está en vuestra mano ayudándome a matar a mi marido temprano".

Acabadas sus razones Carrasco le respondió: "No lo permita Dios, no, que yo haga essas traiciones a quien nunca me ofendió. Haviéndole yo gastado gran parte de su hazienda, no es razón que yo le ofenda y más que le he aniquilado su honra sin tener rienda. (vv. 61-90)

Pedro Carrasco, el amante, se opone rotundamente a la idea y decide dejar de visitar a la mujer. Esta, desesperada, solicita la ayuda de una "tía vieja" -personaje con claras reminiscencias celestinescas- para que le ayude a conseguir, de nuevo, el amor de Pedro Carrasco. Por otro lado, el mercader, Gonzalo Díaz, regresa a la casa con su esposa, pero

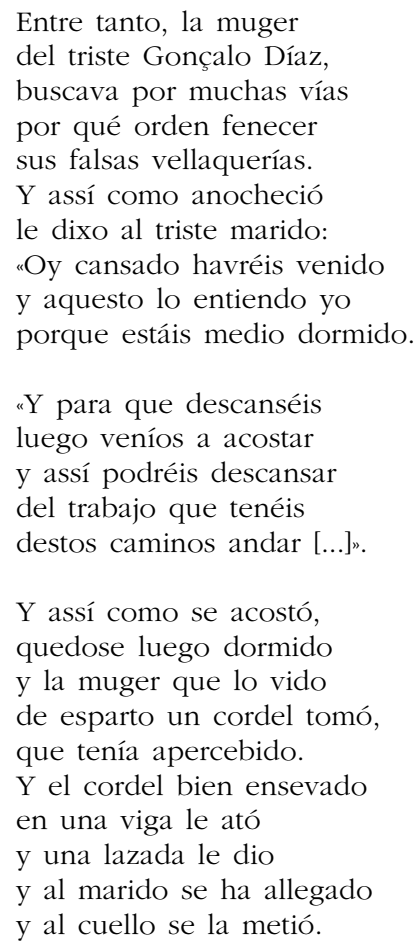


Diole a entender que adobava

la almohada y cabecera

para que mejor durmiera

y en este tiempo le atava

el cordel porque muriera.

Fue lazada escorrediza

la que dexó en el cordel

para que en llegando a él

se escurra por la tomiza

y se ahogue sin tropel. (vv. 191-235)

Pedro Carrasco acude a la casa de la adúltera, engañado por la tía y, finalmente, todos ellos acabarán implicados en la muerte de Gonzalo Díaz, cuyo cadáver arrojan a un pozo. Ahora bien, como señala el autor: "el demonio que hazel estas cosas argüir, lél las viene a descubrir I porque dello a Dios le plazelque se vengan a sentir.. De este modo, pocos días después, una mujer se acercó al pozo para coger agua y entre ella y otros vecinos vinieron a descubrir el cadáver. La justicia civil detendrá primero a la esposa y, como era frecuente en la época, si la confesión no se producía de forma voluntaria, se podía someter al reo a tortura $^{12}$ :

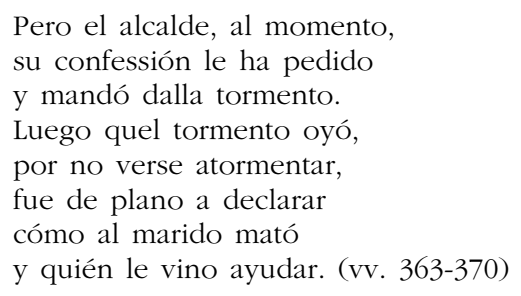

En esta ocasión, según se señala en la composición, no es necesaria la tortura, ya que la mujer confiesa su culpabilidad nada más escuchar que va a ser sometida a tormento. La adúltera, junto con Pedro Carrasco y la tía vieja serán sentenciados a muerte; sin embargo, los castigos serán distintos, ya que la tía se niega a declarar su culpabilidad. De acuerdo con las fases protocolarias que debían seguirse en cualquier proceso judicial de la época, la justicia civil, encarnada aquí en la figura del alcal$\mathrm{de}^{13}$, debe hacer pública la sentencia dictada contra los culpables y así se expresa en el pliego:

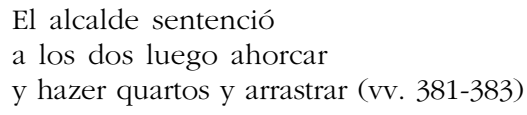

La forma de ejecución más frecuente en Castilla en el siglo XVI era la horca (Tomás y Valiente 1992: 383; Rodríguez Sánchez 1994: 15, n. 6). No obstante, había casi

\footnotetext{
${ }^{12}$ Los estudios e investigaciones en torno a la tortura no son muy numerosos en España, no obstante, destacamos como estudios de conjunto Martínez Díez (1962) y Tomás y Valiente (2000).

${ }^{13}$ Recuérdese que el término 'alcalde' proviene del árabe clásico y significa 'juez', de ahí que la sexta acepción que recoge el DRAE sea 'Juez ordinario que administraba justicia en algún pueblo y presidía al mismo tiempo el concejo', s.v. alcalde.
} 
un sinfín de penas establecidas, aunque no sabemos en cuántas ocasiones llegaron a imponerse. En estas relaciones tremendistas lo cierto es que casi nunca se aplica solamente una y lo más frecuente es encontrar diversos castigos. Parece evidente que esas penas debían de ser bastante conocidas para los oyentes y lectores de este tipo de obras. Como hemos visto hasta ahora, los adúlteros serán castigados con la muerte en la horca y, posteriormente, serán descuartizados. No era infrecuente esta práctica, unida a la exposición de los miembros colgados, ya fuera en el lugar donde se había producido el crimen, en la picota o bien en los caminos o en las puertas de entrada a los pueblos y ciudades. Con este procedimiento se pretendía disuadir a los habitantes o a quienes llegaran a la localidad de cometer algún tipo de delito, manifestando claramente el poder de la justicia:

cuando se llega a cierto nivel de desesperación el miedo no es freno suficiente [...], el miedo a la pena fue muchas veces ineficaz. Se entabla una lucha entre la insensibilización colectiva al sufrimiento ajeno o propio, la necesidad de buscar sustento con frecuencia ilegalmente, las pasiones violentas de una sociedad poco o nada apacible, y la fuerza atemorizadora del rey y su ley. De ahí la complicación rebuscada de muchos tormentos y de muchas ejecuciones de la pena capital. De ahí, por supuesto, la publicidad de las ejecuciones, los pregones y la colocación de los cuartos de los reos en sitios de mucho tránsito (Tomás y Valiente 1992: 357).

Los adúlteros, mientras son conducidos al cadalso, gritan implorando misericordia divina. Por este motivo comprendemos las palabras que Francisco Gónzalez de Figueroa pone en boca de los dos culpados:

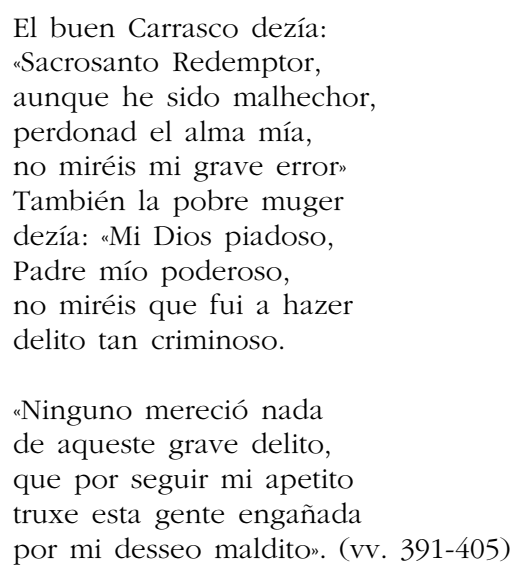

Esto no siempre ocurre en las relaciones tremendistas, pero la inclusión de este aspecto por parte del autor no tiene por qué ser casual. De sobra conocidas para el público eran las Artes moriendi que, desde la Edad Media, enseñaban a prepararse en el tránsito de la muerte. En este sentido, el ajusticiamiento del culpado podía interpretarse como una buena muerte si se arrepentía y moría cristianamente. De este modo cumplía también una función moralizante para los asistentes, dando ejemplo a los demás. Recordemos que en diferentes artes de bien morir se aconsejaba al reo que se arrepintiese de todos los pecados y delitos cometidos para quedar en paz con 
Dios, de ahí que el autor de este caso horrible y espantoso incluya la siguiente apreciación:

\author{
Luego a los dos ahorcaron \\ y, según las muestras dieron, \\ christianamente murieron \\ y con las vidas pagaron \\ el delito que hizieron. (vv. 406-410)
}

Por último, la tía es sometida a tormento para que confiese su culpa y se le aplica una sentencia más rigurosa:

'Que la saquen ahorcar

y después desto a encubar

y la cabeça cortada

para otras avisar'. (vv. 417-420)

Cobra ahora pleno sentido el grabado que encontrábamos en una de las ediciones del pliego, en el que aparecían dos reos en el patíbulo ya ahorcados y el verdugo subiendo a una tercera persona al cadalso. Se establece así una correlación directa entre el texto y el lenguaje visual, ambos se complementan mutuamente, conformando de este modo una unidad plena.

Respecto al segundo castigo que se aplica a esta tercera culpable, sabemos que el método del encubamiento o culleum se aplicó en algunos casos, siguiendo la herencia del derecho romano. La pena consistía en meter al condenado en una cuba con un perro, un mono, un gallo y una serpiente, y arrojarlos al agua. Sebastián de Covarrubias, siguiendo la línea de los bestiarios medievales, explica por qué se introducían estos animales:

Todos estos animales o matan sus padres o sus hijos o sus consortes. La mona al monillo, brincándole y apretándole entre los brazos; el perro, por quitarle el hueso arrojado a su padre, le mordisca y a veces le degüella; el gallo pica a su padre y forma pelea mortal con él sobre tomar las gallinas; la víbora dicen que, concibiendo por la boca, corta la cabeza al macho, acabando de recibir la simiente, y después viboreznos vengan la muerte del padre, que no pudiendo salir a la luz con la presteza que querrían, horadan la barriga de la madre y salen por ella, dejándola muerta [s. v. encubar $]$.

Añade también que

se introdujo una pena en esta forma: encerraban al parricida en un cuero de vaca o en una cuba, echaban dentro con él un perro, una mona, un gallo, una víbora y, cosido muy bien el cuero o embetunada la cuba, lo echaban en el río o en la mar, y sin entrarle dentro el agua se ahogaba con gran tormento y vejación de los animales que le acompañaban" $[s, v . c u b a]$ (Covarrubias 1995).

Además del encubamiento tras la horca, a la "tía vieja" se le corta cabeza:

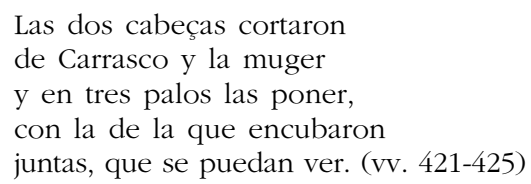


De nuevo observamos el fin moralizante que se perseguía con estas obras y el propio coplero termina su composición exhortando a todos sus oyentes y lectores a que no delincan ni comentan adulterio:

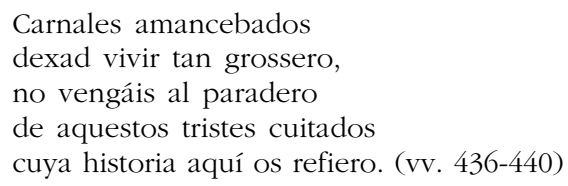

A través de este ejemplo hemos podido comprobar cuál era el final de aquellos que cometían adulterio. En esta y otras relaciones tremendistas de esta temática la mujer adúltera siempre es la inductora y causa principal de los demás delitos que se sucederán y que son provocados por la infidelidad conyugal ${ }^{14}$. En esta relación de sucesos la mujer, para gozar del amor de su amante, mata al marido, pero existen otros ejemplos en los que la adúltera asesina al esposo y a sus cuatro hijos (RM 106), o a la hija y a la suegra (RM 215.5) $)^{15}$ a los padres (RM 233.5), etc. Veamos algún ejemplo más.

La siguiente relación tremendista lleva por título: Obra nuevamente sucedida en el Castillo de Salças, en el reino de Cataluña, la qual trata de un maravilloso milagro que obró Nuestra Señora del Carmen. Trata de cómo una mesonera dio la muerte a su marido y a quatro bijos suyos por irse con un harriero, y de cómo el demonio tomó su figura y los echó dentro en un pozo con sus escapularios. Y de cómo se vistió en traje de varón y se juntó con quinze vandoleros e mataron a tres mercaderes de Valencia y a dos frailes de San Francisco. E por ciertas visiones que vido, se vino a presentar a la iusticia e cómo fue sentenciada a aborcar y estuvo colgada desde las tres de la tarde hasta otro día a las nueve sin morir y, mirándola la iusticia le hallaron el escapulario, y quitándoselo murió. Compuesto por Francisco Casado, vezino de Medina del Campo, en este año de 1595 (RM106).

Los hechos se sitúan en la actual localidad de Salses-le-Château, cerca de Perpiñán, en el Rosellón ${ }^{16}$. El título, amplísimo, resume y pormenoriza la narración que sigue a continuación y que, como bien señala, trata de una mesonera que por irse con otro hombre mató a su esposo y a sus cuatro hijos. Con la lectura de la obra descubriremos que se trata de una mujer muy devota de la Virgen del Carmelo a la que el demonio -disfrazado de arriero- tienta y consigue seducir. La pieza une tremendismo y milagrería casi en las mismas proporciones, ya que una vez que la mujer ha cometido los primeros asesinatos, al verse abandonada por el arriero -ella en ningún momento sospecha que es el mismísimo diablo-, no duda en unirse a un grupo de bandoleros $^{17}$ y seguir cometiendo fechorías y crímenes, que se recrean en los detalles más

${ }^{14}$ No es la primera vez que observamos en estas obras cómo el pecado -aunque sea pequeño- induce a cometer otro tipo de delitos. Aunque de temática distinta al caso que ahora nos ocupa puede verse el siguiente trabajo Sánchez Pérez (2011a). Recordemos, además, que en la época no existe un deslinde claro entre ambos términos: pecado/delito.

${ }^{15}$ Existe edición y estudio pormenorizado de esta obra en Carro Carbajal y Sánchez Pérez (2008).

${ }^{16}$ En efecto, el Castillo de Salças que aparece en el pliego se refiere a la magnífica fortaleza que construyó Fernando II de Aragón en Salses.

${ }^{17}$ No nos detendremos ahora a analizar y detallar el conocido fenómeno del bandolerismo en España. Únicamente queremos recalcar la idea de que precisamente el reino de Aragón, en el siglo XVI, era un importante foco de bandolerismo. 
truculentos y morbosos. Como también señala el título, al final, ella tiene una serie de visiones que rememoran su inicial piedad y devoción a la Virgen, por lo que decide presentarse ante la justicia, que la sentencia a muerte por los crímenes cometidos. Sucederá entonces el milagro: hasta que no se le arrebata el escapulario la mujer no fallece en la horca. Es una obra que finaliza con el arrepentimiento de la mujer y, por lo tanto, los frailes de la orden del Carmelo la enterrarán con gozos y motetes. En la narración se aúnan el morbo y el tremendismo, junto con la religiosidad y el fin ejemplificador.

Hasta ahora hemos visto, fundamentalmente, que la violencia se produce hacia los maridos, que mueren a manos de estas mujeres adúlteras. Sin embargo, existen otros casos en que no solo son asesinados los cónyuges, sino también los padres por casarlas contra su voluntad. Ocurre así, por ejemplo, con la siguiente relación de sucesos: Obra nuevamente compuesta sobre la temerosa, cruel y rigurosa muerte que una dama portuguesa, natural de Coimbra, dio a su padre y madre porque la casaron contra su voluntad. Y de cómo se fue con otro, a quien bien quería. Y de la rigurosa vengança que su esposo tomó del que la llevó. Juntamente con el falso testimonio que ella levantó a su esposo, con que lo traxo a morir sin culpa por justicia, y de la que della bizieron. Con un villancico al cabo que trata de las costumbres que tienen algunas mugeres para atraer a si a los que sienten dineros. Compuesta por Antonio de Govea, lusitano, en este año de 1584 (RM 233.5).

Antonio de Govea, el autor de esta composición, sitúa la acción en Coimbra, donde una joven, llamada Beatriz de Sandoval está perdidamente enamorada del hijo de un escribano. El padre de ella, al conocer la noticia, le comunica que su casamiento ya está concertado con otro hombre. Al oír esto, se dice en la relación:

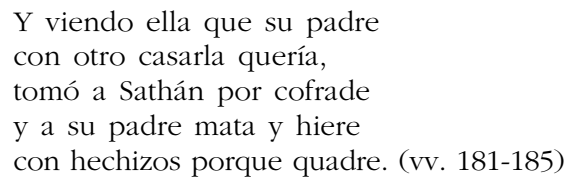

A través de la hechicería la joven consigue asesinar al padre, pero no satisfecha con esto se indica a continuación:

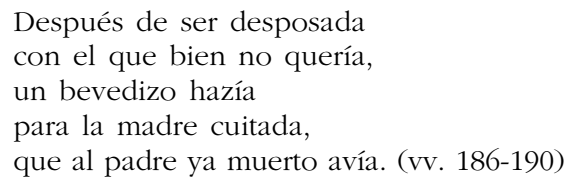

Aunque no se narran los desposorios, sabemos que, antes de celebrarse, Beatriz de Sandoval asesina a su padre y, con posterioridad, a la madre. Se trata de un caso horrible y espantoso en el que la doncella mata a sus progenitores por casarla contra su voluntad. Pero la narración no acaba aquí. Posteriormente, la joven huye con su amante, aunque "poco tiempo durólsu gloria" ya que el marido, ofendido, parte a buscarla. Consigue localizar a la pareja en Zamora y, después de acechar un tiempo a los fugados, mata, de una puñalada, al amante de la joven. El marido, ofuscado, decide en un primer momento asesinar también a su esposa, pero esta le ruega que 
no lo haga y que, a partir de ese momento "haríal todo quanto le mandasse" (vv. 241242). Al final, logra convencerle y deciden partir hacia Valencia. Durante el camino descubren el cadáver de un caballero muerto -a manos de unos ladrones, se nos dice en el pliego- y Beatriz de Sandoval, sin que el esposo se dé cuenta, sustrae un anillo al caballero asesinado. Así llegan a Valencia, donde la justicia civil se encuentra pregonando la recompensa que recibirá quien consiga aportar algún dato sobre la muerte del caballero. La mujer, al oír esto, no duda en vengarse de su marido: decide entonces colocar el anillo debajo de la almohada del esposo, corre después a denunciarlo a la justicia civil que, al instante, se presenta a prenderlo. El autor del pliego señala entonces:

\author{
Hallaron al innocente \\ debaxo la cabecera \\ el anillo que deviera \\ tornarse viento al presente, \\ porque tanto mal no hiciera. (vv. 306-310)
}

La justicia apresa al marido inocente y, para que confiese su delito, lo someten a tortura. En algunas de estas composiciones tremendistas -como en esta que nos ocupa- no se especifica claramente cuál era el tipo de tortura que se imponía en el siglo XVI. Resulta significativo el hecho de que los autores de estos casos horribles y espantosos soslayen en algunas ocasiones este aspecto, pues es evidente que la narración de los tormentos podía dotar a sus obras de mayor tremendismo y, por lo tanto, una descripción detallada de ellos habría ayudado a conseguir uno de los fines que buscaban: provocar temor y espanto en el público.

Volviendo al pliego que analizábamos, el marido se declara finalmente culpable del asesinato del caballero al no poder soportar la tortura:

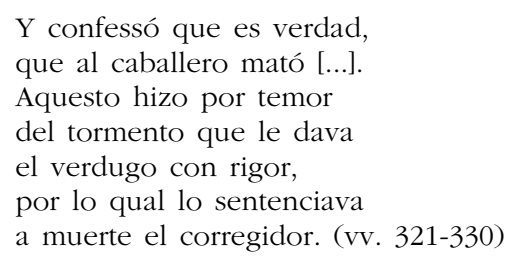

Después de sufrir tormento, el marido es condenado a ser descuartizado y colocar sus miembros colgados por los caminos. Esta era una práctica común que servía de escarmiento y con ella se trataba de intimidar al pueblo para que se abstuviese de cometer delitos. Como ejemplo, baste recodar el comentario que le dirige el Cojuelo a don Cleofás en El Diablo Cojuelo de Luis Vélez de Guevara:

-Mira qué gentil árbol berroqueño, que suele llevar hombres como otros fruta.

-El celebrado rollo del mundo -le respondió el Cojuelo.

-Luego ¿esta ciudad es Écija? -le repitió don Cleofás (Vélez de Guevara 1999: 69).

Célebre en la época era el rollo de Écija que medía cuatro o cinco metros de altura con un león en la parte superior sosteniendo el escudo de la ciudad (Vélez de Guevara 1999: 69). Señalaba Covarrubias: "También es celebrada [Écija] por el rollo o 
horca de piedra entre gente pícara, que para despedir a uno con desaire y menosprecio, le dicen que se vaya al rollo de Écija, que le estire" (Covarrubias 1995, s.v. Écija). Ya nos referimos más arriba a cómo era frecuente dejar los miembros amputados en caminos, puertas de las ciudades, etc., o en los rollos y picotas (Bernaldo de Quirós 1975) que había en algunas localidades, ubicadas en lugares de mucho tránsito como plazas o cruces de caminos $^{18}$.

Volviendo a nuestro pliego, el marido es descuartizado y sus restos colgados por los caminos. Como ocurre siempre en estos casos horribles y espantosos la verdad deberá prevalecer. Por lo tanto, para terminar se nos narra el final de esta mujer asesina y adúltera. Los ladrones que realmente habían asesinado al caballero fueron prendidos cuando cometían otro delito. Sometidos al tormento confesaron todos sus crímenes y, entre ellos, que habían sido los verdaderos culpables del asesinato del caballero, diciendo que el ajusticiado era en realidad inocente. Finalmente, todos los culpables son sentenciados a muerte: los ladrones terminan en la horca, mientras que la mujer será encubada. En los pliegos sueltos en verso del Quinientos, dicho castigo siempre aparecerá destinado a mujeres. Así, por tanto, acaba la vida de Beatriz de Sandoval, quien, como dice el autor: "Veis aquí en qué paról esta moça mal lograda" (vv. 376-377).

Tras un recorrido por algunos de estos pliegos, no nos atrevemos a cuantificar el grado de verosimilitud que tendrían los casos que se nos narran -difícil también resulta distinguir qué era verosímil e inverosímil para un lector/oidor del siglo XVI- y hasta qué punto podrían partir de unos hechos realmente ocurridos, por lo que resulta prácticamente imposible demostrar si los hechos narrados sucedieron realmente o no -aunque se vinculen a la labor noticiera e informativa que tenían estos textos-.

A través de estos ejemplos lo que es evidente en esta literatura de cordel es la vigencia que existía de la imagen y el estigma de la mujer vista como Eva, es decir, como pecadora, falsa, cruel y caprichosa: “iMujeres o demonios? Para la Iglesia y para un determinado sector del pensamiento laico la identificación es plena" (MartínezBurgos García 1996: 101). La tradición judeocristiana que reservaba a las mujeres el rol exclusivo de buenas o malas, dependiendo de su asignación al papel de Eva o por el contrario, al de la Virgen María, ha pesado durante muchos siglos en el imaginario colectivo de la sociedad europea. Los Padres de la Iglesia habían asociado a las mujeres bien con María y, por lo tanto, como seres virginales, angelicales, virtuosas, etc., o bien con Eva, es decir, la culpable del pecado original, identificada desde entonces con la sexualidad, el pecado y el mal. En la Península Ibérica, y centrándonos en este caso en el siglo XVI, esta idea gozaba de buena salud, como hemos visto, más si cabe tras los edictos formulados en el Concilio de Trento. En efecto, en los ejemplos que hemos analizado la mujer es señalada como un auténtico instrumento de perdición, de ahí que se las tache de ociosas, lujuriosas, pecadoras, libidinosas, lascivas, etc. Nos hallamos ante el estigma de la mujer como un ser malo y peligroso por naturaleza que podía amenazar la dominación patriarcal.

Durante el siglo XVI -y aun después- los libros de espiritualidad, las instrucciones de los confesores y los moralistas, los sermones, etc. se referían una y otra vez al

${ }^{18}$ En diferentes pueblos y ciudades de la Península aún se conservan esos rollos y picotas, al ser declarados bienes de interés cultural. 
sexo y a las funciones que debía desempeñar la mujer. En esta época, todas ellas vivieron supeditadas al dominio del varón, ya fuera padre, hermano o esposo, "toda mujer, fuera noble o plebeya, sufría la opresión impuesta por una cultura patriarcal cuyas relaciones de poder la clasificaban según su estado de soltera, casada, viuda o monja, sujetándola al control masculino" (Cruz 1996: 47). En esta situación, la mujer solo tenía dos opciones: o acatar el rol que la sociedad androcéntrica le había asignado, o intentar rebelarse contra ella, en cuyo caso, se consideraba que debería ser siempre castigada.

Con estas premisas parece evidente que todas estas narraciones de adúlteras poseían un claro fin ejemplificador. Por una parte, se trataba de respaldar la ideología dominante y el orden establecido, en el sentido de que todos los culpables acabarían siendo castigados y ajusticiados por sus delitos; y, por otra, se intentaba aleccionar, atemorizar y disuadir a las mujeres para no verse tentadas por la lujuria.

En el siglo XVI -y también el XVII- el adulterio femenino era un tema obsesivo y ampliamente condenado, debido a su asociación con la pérdida de la honra y la fama; sin embargo, en el caso de las relaciones tremendistas sobre adúlteras hay también otros elementos que sustentan su éxito y su pervivencia hasta mediados del siglo xx: la morbosidad y el gusto por las narraciones de asesinatos, torturas, castigos y ejecuciones explican la difusión masiva y el éxito de estas relaciones sobre violencia y adulterio femenino.

\section{BIBLIOGRAFÍA CITADA}

Askins, A. L.-F. 1981. Pliegos poéticos del siglo XVI de la biblioteca Rodríguez Moñino. Madrid: Joyas Bibliográficas.

Bazán, I. 2006. "Mujeres, delincuencia y justicia penal en la Europa medieval. Una aproximación interpretativa", en Córdoba de la Llave, R. (coord.), Mujer, marginación y violencia entre la Edad Media y los tiempos modernos: 48-53. Córdoba: Universidad de Córdoba.

Bazán, I. 2007. "La pena de muerte en la Corona de Castilla en la Edad Media". Clío E Crimen 4: 306-352.

Bégrand, P. 2006. Las relaciones de sucesos: relatos fácticos, oficiales y extraordinarios. Besançon: Presses Universitaires de Franche-Comté.

Bégrand, P. 2009. Representaciones de la alteridad, ideológica, religiosa, bumana y espacial en las relaciones de sucesos, publicadas en España, Italia y Francia en los siglos XVI-XVIII. Besançon: Presses Universitaires de Franche-Comté.

Bernaldo de Quirós, C. 1975. La picota. Madrid: Turner.

Caro Baroja, J. 1990. Ensayo sobre la literatura de cordel. Madrid: Istmo.

Carro Carbajal, E. B. y Sánchez Pérez, M. 2008. "Estudio y edición del Caso afortuito que agora nuevamente succedió en la ciudad de Fina (Tarragona: Felipe Roberto, 1588). Per Abbat 6: 97126.

Cátedra, P. M. 2002. Invención, difusión y recepción de la literatura popular impresa (siglo XVI). Mérida: Editora Regional de Extremadura.

Civil, P., Crémoux, F. y Sanz, J. (eds.). 2008. España y el mundo mediterráneo a través de las relaciones de sucesos (1500-1750). Salamanca: Universidad de Salamanca.

Covarrubias, S. 1995. Tesoro de la Lengua Castellana o Española. Ed. Felipe C. R. Maldonado. Madrid: Castalia.

Cruz, A. J. 1996. "La búsqueda de la madre: psicoanálisis y feminismo en la literatura del Siglo de Oro", en Saint-Saëns, A. (dir.), Historia silenciada de la mujer. La mujer española desde la época medieval hasta la contemporánea: 39-64. Madrid: Editorial Complutense. 
Delgado Casado, J. 1996. Diccionario de impresores españoles (siglos XV-XVII). Madrid: Arco Libros, 2 vols.

Espejo Cala, C. (coord.). 2008. Relaciones de Sucesos en la Biblioteca de la Universidad de Sevilla. Sevilla: Universidad de Sevilla.

Estella, D. 1787. Tratado de la vanidad del mundo dividido en tres libros. Madrid: Imprenta de Joseph Otero.

Ettinghausen, H. 1995. "Política y prensa 'popular' en la España del siglo XVII". Anthropos 166-167: 86-91.

García de Enterría, M. C. 1982. Pliegos poéticos españoles en Bibliotecas de Portugal. Madrid: Joyas Bibliográficas.

García de Enterría, M. C. 1983. Literaturas marginadas. Madrid: Playor.

García de Enterría, M. C. 1990. "El cuerpo entre predicadores y copleros", en Redondo, A. (ed.), Le corps dans la société espagnole des XVI et XVII siècles: 233-244. París: Publications de La Sorbonne.

García de Enterría, M. C. et al (eds.). 1996. Las relaciones de sucesos en España (1500-1750). Actas del I Coloquio Internacional. París y Alcalá de Henares: Publications de La Sorbonne-Publicaciones de la Universidad de Alcalá.

Instrumentos de tortura. Guía de la exposición de Instrumentos de Tortura desde la Edad Media a la Época Industrial, presentada en diversas ciudades del mundo. 1983-2000 [s. 1., s. n.].

León, L. 1968. La perfecta casada. Madrid: Espasa-Calpe.

López Poza, S. (ed.). 2006. Las noticias en los siglos de la imprenta manual: homenaje a Mercedes Agulló, Henry Ettinghausen, M. ${ }^{a}$ Cruz García de Enterría, Giuseppina Ledda, Augustin Redondo y José Simón. A Coruña: SIELAE y Sociedad de Cultura Valle Inclán.

López Poza, S. y Pena Sueiro, N. (eds.). 1999. La fiesta. Actas del II Seminario de Relaciones de Sucesos. Ferrol: Sociedad de Cultura Valle Inclán.

Martínez-Burgos García, P. 1996. "Bajo el signo de Venus: la iconografía de la mujer en la pintura de los siglos XVI y XVII", en Saint-Saëns, A. (dir.), Historia silenciada de la mujer. La mujer española desde la época medieval hasta la contemporánea: 95-123. Madrid: Editorial Complutense.

Martínez Díez, G. 1962. "La tortura judicial en la legislación histórica española". Anuario de bistoria del derecho español. 32: 223-300.

Mendoza Garrido, J. M. 2008. "Mujeres adúlteras en la Castilla medieval. Delincuentes y víctimas". Clio \& Crimen 5: 151-186.

Paba, A. (ed.). 2003. Encuentro de civilizaciones (1500-1750): informar, narrar, celebrar. Alcalá de Henares y Cagliari: Universidad de Alcalá y Universitá degli Studi di Cagliari.

Portús Pérez, J. 2000. "Imágenes de cordel”, en Díaz G. Viana, L. (coord.), Palabras para el pueblo: I, 403-428. Madrid: CSIC.

Proyecto de investigación "Cultura popular y cultura impresa: corpus, edición y estudio de la literatura de cordel de los siglos XVI y XVII" [BFF2003-00011]. Guía para los miembros del equipo y colaboradores. 2003. Salamanca: SEMYR.

Redondo, A. 1995a. "Las relaciones de sucesos en prosa (siglos XVI y XVII)". Anthropos 166-167: 51-59.

Redondo, A. 1995b. "Características del 'periodismo popular' en el Siglo de Oro". Anthropos 166-167: 80-85.

Rivera, O. 2006. La mujer y el cuerpo femenino en 'La perfecta casada' de Fray Luis de León. Newark, Delaware: Juan de la Cuesta.

Rodríguez Moñino, A. 1997. Nuevo Diccionario Bibliográfico de Pliegos Sueltos Poéticos. Siglo XVI. Edición corregida y actualizada por A. L.-F. Askins y V. Infantes. Madrid: Castalia y Editora Regional de Extremadura.

Rodríguez Sánchez, Á. 1994. "La soga y el fuego. La pena de muerte en la España de los siglos XVI y XVII". Cuadernos de historia moderna 15: 13-40.

Sánchez Pérez, M. 2005. "La retórica de las relaciones tremendistas del siglo XVI", en San José, J. (coord. y ed.), Praestan labore Victor. Homenaje al profesor Víctor García de la Concha: 217234. Salamanca: Universidad de Salamanca.

Sánchez Pérez, M. 2011a. "La escalada del crimen en la mentalidad del siglo xvi en una relación de sucesos de 1588". Nueva Revista de Filología Hispánica 59, 1: 173-195. 
Sánchez Pérez, M. 2011b. "La transmisión y difusión de los casos horribles y espantosos desde sus orígenes hasta el siglo XXI", en Cabello, A. et al. (eds.), En los márgenes del canon. Aproximaciones a la literatura popular y de masas escrita en español (siglos 20 y 21): 205-218. Madrid: CSIC-La Catarata.

Tomás y Valiente, F. 1992. El Derecho penal de la monarquía absoluta (siglos XVI, XVII y XVIII). Madrid: Tecnos.

Tomás y Valiente, F. 2000. La tortura judicial en España. Barcelona: Crítica.

Vélez de Guevara, L. 1999. El Diablo Cojuelo. Ed. de R. Valdés, estudio preliminar de B. Periñán. Barcelona: Crítica.

Vives, J. L. 1935. Instrucción de la mujer cristiana. Trad. J. Justiniano. Madrid: Signo.

Fecha de recepción: 11 de septiembre de 2012

Fecha de aceptación: 11 de junio de 2013 